\title{
From surge-type to non-surge-type glacier behaviour: midre Lovénbreen, Svalbard
}

\author{
SIRI HANSEN \\ Institute of Geography, University of Copenhagen, Øster Voldgade 10, DK-1350 Copenhagen, Denmark \\ E-mail:sh@geogr.ku.dk
}

\begin{abstract}
Since the beginning of the 1900 s, the polythermal valley glacier midre Lovénbreen (area $5 \mathrm{~km}^{2}$ ) in northwestern Svalbard has retreated approximately $1 \mathrm{~km}$. The glacier has not surged for at least 110 years, and the present smooth longitudinal profile and negative mass balance suggest that it is not currently building up to a surge. Based on limited evidence, it has often been assumed that midre Lovénbreen surged around 1880. The ongoing retreat is probably due to quiescent-phase stagnation amplified by 20thcentury climate change, as is the case for several other glaciers in Svalbard. Recently, small eskers have been found in the glacier forefield. Based on their geomorphological appearance, these are interpreted as concertina eskers, and they add to the dynamic history of the glacier. Midre Lovénbreen is interpreted as an example of a change from surge-type to non-surge-type glacier behaviour.
\end{abstract}

\section{INTRODUCTION}

Svalbard is a region with an unusually large proportion of surge-type glaciers; the most recent estimates are $36 \%$ (Hamilton and Dowdeswell, 1996) and 13\% (Jiskoot and others, 2000). The surge cycle for Svalbard ice masses is 50 500 years, which is relatively long (Dowdeswell and others, 1991), and only a few of these have more than one observed surge (Hagen and others, 1993). Svalbard has a high-Arctic climate with continuous permafrost, and hence probably no entirely wet-based glaciers. The smallest cirque glaciers are frozen through the entire ice mass, but most of the glaciers are polythermal, with margins and parts of the ablation area below the freezing point, and the accumulation area and the deepest part of the ablation area at the pressure-melting point (Hagen and others, 1993). The Little Ice Age (LIA) maximum occurred around 1900 in Svalbard (Lefauconnier and Hagen, 1991), and many glaciers had negative mass balances for most of the 20th century, resulting in considerable volume decreases (Hagen and Liestøl, 1990; Hagen and others, 1993; Dowdeswell and others, 1997). When climate is changing, it may be difficult to tell whether a glacier is retreating due to negative mass balance or because it is in the quiescent state of a long surge cycle. In Svalbard, persistently negative mass balances may have changed the frequency and occurrence of glacier surges (Dowdeswell and others, 1995).

Glacier surges are spectacular events, but can be difficult to detect if the surge is not observed. Ice-surface features characteristic of active surging include widespread, chaotic crevassing, marginal shearing and sudden terminus advance (Dowdeswell and others, 1995). The classification of surging glaciers in Svalbard and elsewhere is usually based on a combination of supraglacial and proglacial morphological evidence and records of advances (Sharp, 1985, 1988; Liestøl, 1993; Knudsen, 1995; Hamilton and Dowdeswell, 1996; Evans and others, 1999; Jiskoot and others, 2000). Some of the small valley glaciers in Svalbard have been classified as being of the surge type, even though they have never been observed during an active phase. These classifications were based either on observations of steep glacier fronts, standing several hundreds of metres in front of the present glacier snout (e.g. Liestøl, 1988), or on the presence of certain geomorphological features in deglaciated areas (Hambrey and Dowdeswell, 1997; Evans and Rea, 1999; Hart, 1999).

\section{Landforms developed by ice compression}

In polythermal glaciers, sliding velocity decreases in the transitional zone between the warm-based ice in the interior of the glaciers and the cold-based ice near the margin, resulting in flow compression. Subglacially derived sediment can be incorporated in the glacier by thrusting (Hambrey and others, 1999). Not all the thrusts necessarily reach the surface, but they are subsequently stacked and are released and left when the glacier retreats (Bennett and others, 1996; Hambrey and others, 1996, 1997, 1999). Since glacier surging is associated with flow compression and widespread subglacial and proglacial glacitectonic deformation (Raymond and others, 1987; Benn and Evans, 1998), similar thrusts may form during a surge. The development of widespread glacial thrusting is thus associated with either polythermal ice margins or glacier surges (Bennett and others, 1996; Hambrey and others, 1996), and so is not unequivocal evidence of surge-type behaviour.

Eskers left by non-surging glaciers are typically winding ridges, but if the glacier velocity increases significantly, as during a surge, compressive flow near the glacier snout leads to glacial deformation, and existing sinuous eskers may either be completely destroyed or be compressed in the ice-flow direction (Knudsen, 1995). Compressed zigzag-shaped eskers, called concertina eskers, found in a deglaciated area therefore indicate variations in glacier velocities over time and are good indicators of surge behaviour (Knudsen, 1995).

The small valley glacier midre Lovénbreen on Svalbard 


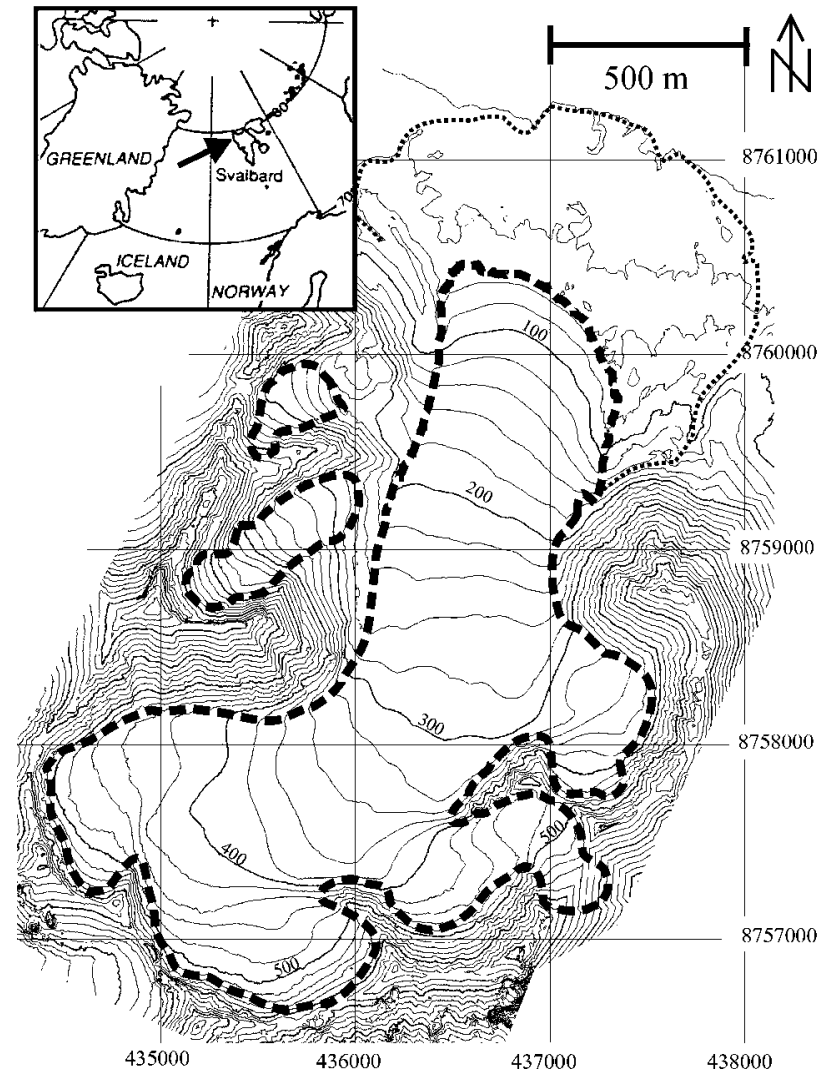

Fig. 1. Location of the study site and terrain model of midre Lovénbreen. The thick dashed lines are the 1995 outline of the glacier and the small detached glaciers. The outer limit of the end moraine is dotted. The grid is in Universal Transverse Mercator (UTM) coordinates.

has not surged for at least 110 years, and the modern appearance with a lack of build-up is not consistent with the quiescent phase of a surge cycle. However, small ridges in the shape of concertina eskers in the glacier foreland suggest that the glacier has surged in the past.

The aim of this study is to investigate whether midre Lovénbreen did surge in historical time and thus may represent an example of dynamic change from surge-ty pe to nonsurge-type glacier behaviour. The study is based on geomorphological field mapping in 1997, aerial-photographic interpretation and mass-balance reconstructions.

\section{MIDRE LOVÉNBREEN}

Midre Lovénbreen is a small valley glacier, which presently covers about $5 \mathrm{~km}^{2}$ in northwestern Svalbard $\left(78^{\circ} 53^{\prime} \mathrm{N}\right.$, $12^{\circ} 04^{\prime} \mathrm{E}$ ) (Fig. 1). It is $4.2 \mathrm{~km}$ long and approximately $1 \mathrm{~km}$ wide at the equilibrium-line altitude (ELA), and it drains ice from four small cirques. Two other cirques along the western margin are detached from the main glacier. The maximum glacier altitude is $660 \mathrm{~m}$ a.s.l. and the elevation of the visible front is $45-50 \mathrm{~m}$ a.s.l.

Mass-balance investigations have been carried out by the Norwegian Polar Institute (NPI) every year since 1967/68 (e.g. Hagen and others, 1993). Net balances have been negative for almost all years, with an average of $-0.35 \mathrm{~m} \mathrm{a}^{-1}$ w.e. The accumulation-area ratio has fluctuated between $0 \%$ and $77 \%$ with a mean of $35 \%$ of the glacier surface area. The average ELA was $395 \mathrm{~m}$ a.s.l. during the period 1967| 68-1990/91. Surface velocity, measured by NPI in most years

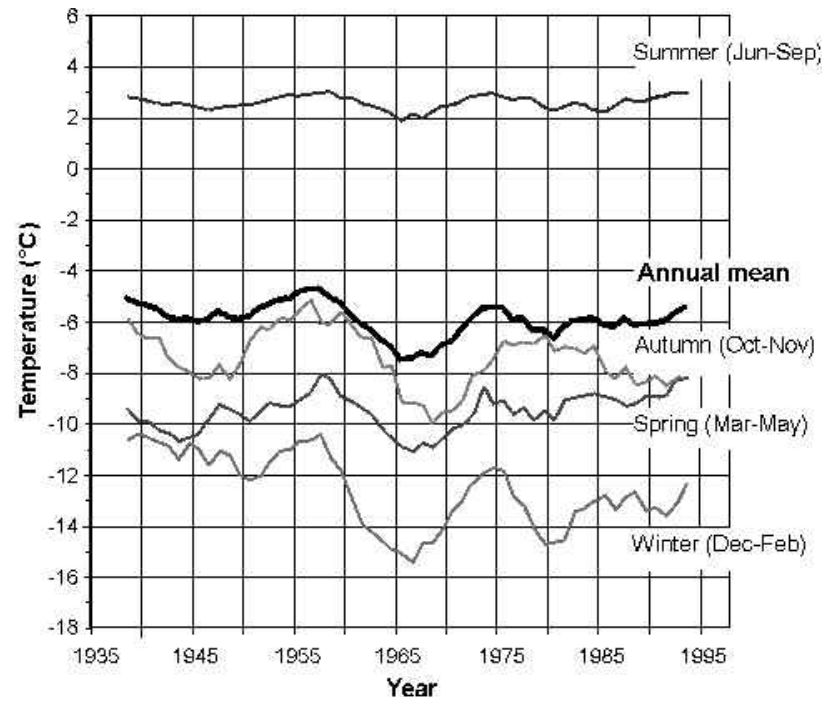

Fig. 2. Air temperature in Ny-Alesund, 1935-96 (data obtained from the DNMI): 7 year running means for each season. To give an overview of the temperature development during the century, the months are grouped into seasons. The seasons are defined according to the linear tendencies in temperature change over the 61 year period. March-May: a small increase; Fune-September: no change; October-November: a small decrease; and December-February: decrease.

since 1970, is very slow. Close to the ELA, the velocity is $4.5 \mathrm{~m} \mathrm{a}^{-1}$, which is also regarded as being the balance velocity (Björnsson and others, 1996), although Hagen and Liestøl (1990) noted that the ice flux along the glacier is exceeded by ablation in the lower part. If this is the case, either the glacier is melting back or the surface gradient is becoming steeper and may eventually result in a surge. However, the surface slopes gently, the longitudinal profile is smooth (Fig. 1), the front is thin and the glacier has very few crevasses and does not seem to be building up in the accumulation area.

The maximum ice depth recorded by radio-echo sounding in 1988 was $178 \mathrm{~m}$ (Hagen and Sætrang, 1991). The glacier is cold-based along the valley sides and up to a distance of $\sim 1000 \mathrm{~m}$ up-glacier from the front, whereas it has a warm basal layer (up to $50 \mathrm{~m}$ thick) beneath the central part. The ice temperature reaches the pressure-melting point at about 105-110 m depth (Björnsson and others, 1996).

\section{Glimate in the 20 th century}

Svalbard has a maritime Arctic climate influenced by the northern limit of the North Atlantic Drift. Midre Lovénbreen is situated only $5 \mathrm{~km}$ southeast of the weather station in $\mathrm{Ny}$ Ålesund, where several meteorological parameters have been measured continuously since 1969 . The mean air temperature (1975-96) is $-5.7^{\circ} \mathrm{C}$, and measured precipitation is around $400 \mathrm{~mm} \mathrm{a}^{-1}$ w.e. (personal communication from I. HanssenBauer, 1997). The Norwegian Meteorological Institute (DNMI) has reconstructed monthly mean temperatures back to 1934 (Nordli and others, 1996; Førland and others, 1997). Temperature has fluctuated over the years, but summer temperatures have been remarkably stable (Førland and others, 1997; Fig. 2).

\section{EARLY OBSERVATIONS ON MIDRE LOVÉNBREEN}

InJuly 1892 a steep and almost vertical glacier front was posi- 
tioned at the outermost end-moraine, according to visual observations and photographs (Hamberg, 1894). This has been interpreted as an indication of a surge taking place sometime between 1860 and 1880 (Liestøl, 1988) or, alternatively, around 1890 (Hagen and others, 1993). On the old photographs, the almost vertical front seems to lack crevassing, indicating that the glacier was probably not advancing in 1892 (Liestøl, 1988). Other glaciers in the area had a similar appearance at the time (Hamberg, 1894), and therefore nearby austre Brøggerbreen was also classified as a surge-type glacier by Hagen and others (1993). A more recent interpretation is that the steep, advanced glacier fronts represent a normal LIA maximum advance frontal appearance, as argued by Hansen (1999) and Jiskoot and others (2000). In 1907, Isachsen observed and photographed glaciers in the area, including midre Lovénbreen (Isachsen, 1912). All six observed glaciers were at their maximum extent at the time, with convex fronts standing at the outermost frontal moraines. In 1923, the glacier fronts remained at or very close to their maximum extent (photograph published in De Geer, 1930). Since then, midre Lovénbreen and its forefield have been captured by aerial photography by NPI in 1936, 1948, 1966, 1969, 1971, 1977, 1990 and 1995, allowing the retreat rate to be established.

\section{GEOMORPHOLOGIGAL EVIDENGE FOR PAST SURGE-TYPE BEHAVIOUR}

\section{Observations in the glacier forefield}

As interpreted from photographs and field observations, the glacier has retreated almost $1 \mathrm{~km}$ over the past $\sim 100$ years and deposited a till landscape bordered by a well-defined semicircular ridge of end moraines up to $20 \mathrm{~m}$ high (Fig. 3). In some places this moraine has a central core of ice, as indicated by slumping. Beyond the terminal moraine an outwash plain slopes very gently for $1 \mathrm{~km}$ to the bay Kongsfjorden. The active glacier front is a well-defined line, although the glacierproximal part of the forefield consists of dead ice and is experiencing scattered collapse and surface lowering due to the melting of buried ice. The central part of the forefield is characterized by patches of ice-cored moraine, smooth areas of ground moraine and small eskers, whereas the more glacier-distant part of the glacier forefield is irregular, with several small moraine mounds of $1-15 \mathrm{~m}$ and a relief generally below $7 \mathrm{~m}$. Hambrey and others (1997) attributed these moraine mounds to thrusting in active polythermal ice. The surface is covered by glacial and fluvioglacial sediments dominated by coarse-grained material of $5-20 \mathrm{~cm}$ (field estimate). Glaciofluvial resedimentation is common, and numerous active or abandoned braided meltwater streams and small lakes dominate the area.

Characteristic elongated concentrations of angular, coarse-grained debris are melting out of the active glacier front in sub-parallel trains up to $200 \mathrm{~m}$ long. These $5-8 \mathrm{~m}$ wide and $<0.5 \mathrm{~m}$ high bands have a regular, almost parallel appearance, indicating that the source ice has not been deformed by longitudinal compression since the debris entrainment. Similar debris bands on neighbouring austre Lovénbreen were interpreted by Hambrey and others (1999) as the hinge lines of tight longitudinal folds .

The mantle of glacial and fluvial deposits may be thin in some areas, as scattered rock outcrops are found in the glacial forefields of midre Lovénbreen and austre Lovén- breen. This implies that stagnated, debris-covered glacier ice is unevenly distributed and that in some parts of the area the sediment layer is very thin, whereas it may be much thicker between the rock outcrops.

Small, irregular eskers are found in the glacier forefield superimposed on the flat moraine landscape (Fig. 3). Several small sections of eskers are scattered through the area, most of which are no more than a few metres long. Subglacial meltwater is not present at the bed when the glacier sole is frozen, so the polythermal temperature regime of the glacier implies that the eskers are likely to have formed englacially or supraglacially. This is thought to be the cause of the irregularity: as the eskers melt out they are draped over the underlying sediments and presumably over dead ice and permafrost. Redistribution by meltwater may also have removed pieces of the shallow ridges.

\section{Deformed eskers}

In a few places, approximately $500 \mathrm{~m}$ in front of the active glacier front, eskers seem to have been deformed. Instead of winding ridges, these eskers are made up of sharp bends and straight sections between the bends (Fig. 4). Compared to the concertina eskers in Iceland described by Knudsen (1995) and Evans and others (1999), the eskers in front of midre Lovénbreen are small. Their maximum heights are 1-2 m, and the unfolded lengths are $80 \mathrm{~m}$ at most.

Cross-profiles were excavated to determine the internal structure of the eskers. A layer of up to $18 \mathrm{~cm}$ of well-sorted, laminated sand was overlain by irregular layers of a few $\mathrm{cm}$ of coarse, well-sorted gravel, alternating with unsorted gravel. The well-sorted layers were interpreted as fluvially deposited sediments. The slabs of bedded sediments were adjacent to bodies of unsorted diamictons. These disturbed or even structureless sediments are not well-preserved, stratified sediments as would be expected in supraglacial tunnel fills. This appearance is consistent with subglacially and englacially derived eskers (Brennand, 1994; Benn and Evans, 1998). Change of esker sediments from horizontally sorted sequences to massive, unsorted sediments indicates a change of flow conditions in the esker tunnel (Knudsen, 1995). The deformed, bedded sediments found in some cross-profiles indicate sedimentation by running water in at least some phases of tunnel filling. During a surge event, the esker sediments behave as part of the surging ice and are thus deformed and fractured (Knudsen, 1995).

It is worth considering whether such eskers can form by some process other than during a surge and whether they may be older than the most recent glaciation of the area. An alternative explanation is that they are crevasse-fill ridges formed by the flow of subglacial sediment into open basal crevasses at the cessation of a glacier flow (Bennett and others, 1996), but the partly bedded structure of the sediments contradicts this interpretation. Landforms can in some cases be preserved even if overrun by a cold-based glacier, but in conditions of extreme advance and deformation it is more likely that features in front of the glacier will be completely destroyed or buried (Knudsen, 1995). It is therefore suggested that the eskers were englacially deformed during a surge and became subaerially exposed during the most recent phase of deglaciation.

This assertion leads to the question of midre Lovénbreen's status in the surge classification. Hamilton and Dowdeswell (1996) classified midre Lovénbreen as a normal, non-surge- 


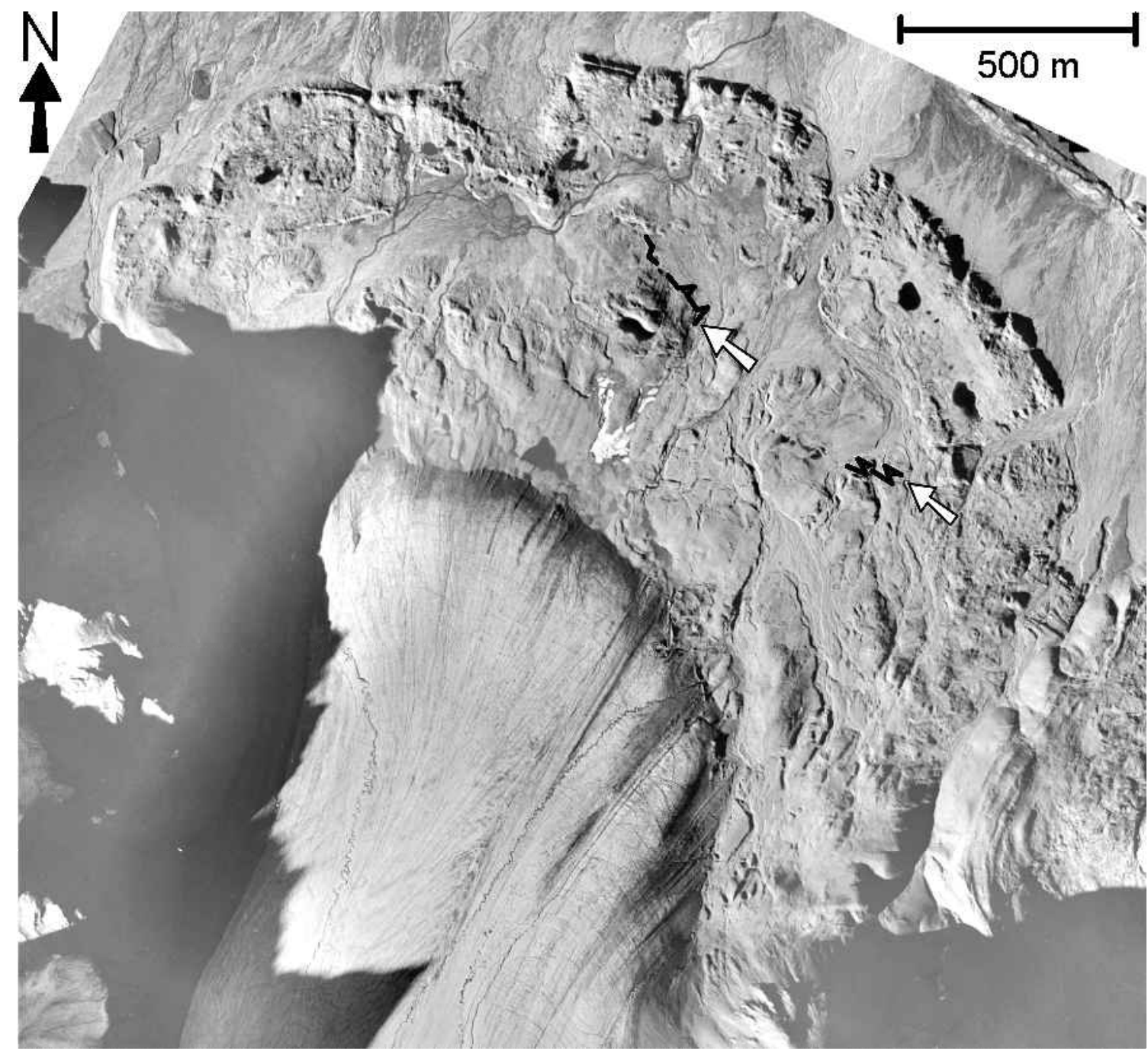

Fig. 3. Georeferenced orthophoto of terminus and the proglacial area of midre Lovénbreen in 1995. Deformed eskers are most pronounced at the white arrows. The esker shown in Figure 4 is at the arrow in the centre of the proglacial area. Aerial photographs S95 1069-1071, 1082-1084, (C) Norwegian Polar Institute.

type glacier (personal communication from G. S. Hamilton, 2002), as did Hambrey and others (1999) and Jiskoot and others (2000).

\section{REGONSTRUGTION OF THE 20TH-GENTURY GLACIER HISTORY}

A combination of field data, aerial photographs, mass-balance measurements and climate data has made it possible to construct a detailed 20th-century history of midre Lovénbreen.

\section{Analysis of glacier and landscape from aerial photo- graphs}

The aerial photographs from 1995 were processed by digital photogrammetry, using Leica Helava's SOCET SET software. The original photographs had large parallax displacements due to the relatively low flying altitude and a terrain varying between sea level and $776 \mathrm{~m}$ a.s.l. Therefore, the landscape was somewhat distorted, and the images not suitable for accurate measurements. The scanned images were corrected and aerotriangulated (georeferenced) by treating them as stereo models. Afterwards, a digital terrain model and a composite orthophoto mosaic of the area were produced for landscape survey (Figs 1 and 3). The surface area of midre Lovénbreen has diminished by approximately $25 \%$ during the 20th century, as revealed by measurements made from the aerotriangulated photographs. Several of the present landscape elements, including the small eskers, can be identified in older photographs, as well as in the 1995 terrain model.

\section{Climate and mass balance}

A reconstruction of the 20th-century mass balance was undertaken in order to determine whether climate is the only reason for the retreat. Temperature data from Svalbard Airport ( $100 \mathrm{~km}$ southeast of midre Lovénbreen) make it possible to statistically estimate net balance as far back as 1911/12.

The specific net balance mirrors the annual fluctuations of the summer balance and not the more consistent values for winter accumulation. This correlation between summer balance and net balance is quite common (Dowdeswell and others, 1997). The linear regression between the ELA and the annual net mass balance $\left(b_{\mathrm{n}}\right)$ in the period $1967-97$ is very good. The regression equation, ELA $=305.78 b_{\mathrm{n}}+289.14$, has an $r=0.94(n=28)$. Net balance has previously been shown to correlate best with the sum of positive degree-days during the melt season (Hagen and Liestøl, 1990; Fleming and others, 1997). Summer temperatures have shown a stable trend during recent decades (Fig. 2), and these provide a good tool for estimating the mass balance. Several regression analyses between single and multiple meteorological factors 


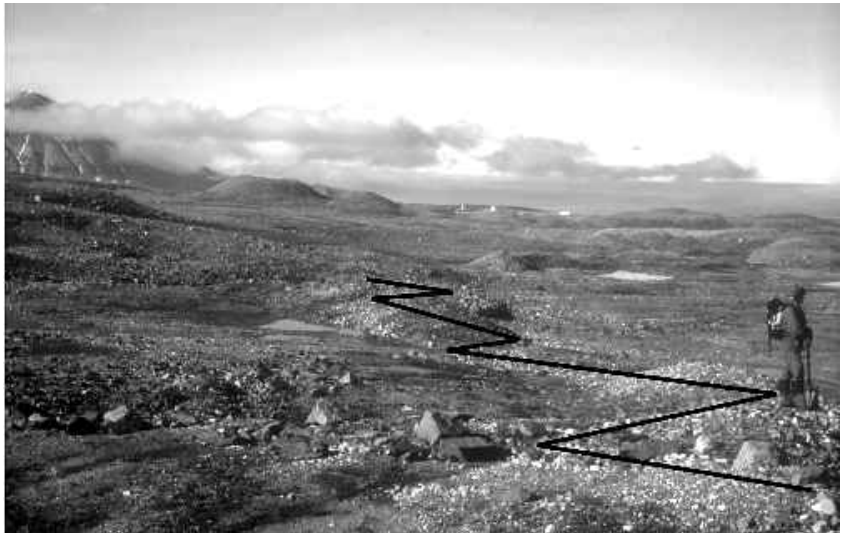

Fig. 4. Small concertina esker, seen towards northwest. See location in Figure 3. The crest is marked. As an estimate based on the 1948 and 1966 aerial photographs, this area became subaerially exposed in the late 1950s. Photograph by the author, 1997.

and mass balance have been made for the present study. The best linear regression with 1969-97 monthly mean temperature data from $\mathrm{Ny}$-Ålesund is

$$
\begin{aligned}
b_{\mathrm{n}}= & 0.3476\left(\text { July }_{\text {mean }}+\text { August }_{\text {mean }}\right) \\
& -0.0303\left(\text { September }_{\text {mean }}\right)+1.1920
\end{aligned}
$$

which has an $r^{2}=0.57$. The best linear regression with 1969 97 monthly mean temperature data from Svalbard Airport is

$$
\begin{aligned}
b_{\mathrm{n}}= & -0.2793\left(\text { July }_{\text {mean }}\right) \\
& -0.0262\left(\text { September }_{\text {mean }}\right)+1.3512
\end{aligned}
$$

which has an $r^{2}=0.54$.

The constructed mass-balance series shows that midre Lovénbreen had a positive balance at the beginning of the 20th century, which is consistent with the historical observation of a steep glacier front. The retreat from the LIA moraine must have been initiated later than 1892, and studies of topographic profiles and glacier front positions along 13 reconstructed flowlines suggest that the retreat of the glacier front initiated around 1925. The retreat rate has been quite stable, although the recession is not equally distributed along the front.

By using temperature data from Svalbard Airport since 1911, the total loss of ice thickness is calculated to be $25 \mathrm{~m}$ w.e., and the mass balance has been negative almost every year since 1918. When the Ny-Ålesund temperature data (since 1934; Fig. 2) are tentatively extended backwards, they yield a slightly larger loss of $27 \mathrm{~m}$ w.e. since 1911.

Fleming and others (1997) modelled the sensitivity of the glacier to future and past changes in climate, but did not consider future or past surge behaviour. It is worth noting that the mass-balance models for midre Lovénbreen in previous studies, as well as the reconstructed net balances in the present study, are based on relatively recent data and that climatic measurements from a period of glacier advance do not exist.

\section{DISGUSSION}

The links between climate change and the occurrence of surges are still unclear (Sharp, 1988), but it is generally accepted that surge events are not directly related to climate change (e.g. Meier and Post, 1969; Sharp, 1985; Hagen and others, 1993). However, in the case of small valley glaciers in
Svalbard, climate probably does play an important role in the surge cycle. Polythermal glaciers tend to surge less frequently, surge at slower speeds and have longer-duration surges than temperate glaciers (Dowdeswell and others, 1991; Murray and others, 2000). Surge periods lengthen as a result of consistently negative mass balances (Dowdeswell and others, 1995). As longitudinal profiles flatten, glacier margins thin, cold temperatures can penetrate the entire ice column and larger fractions of glaciers do not reach the pressure-melting point and hence freeze to their bed. Thus, mass-balance change may cause a change of thermal regime and cause glaciers to switch from surge-type to non-surgetype (Dowdeswell and others, 1995). This may have been the case for midre Lovénbreen.

The predominantly negative mass balances of midre Lovénbreen during the past 85 years and the lack of a build-up of mass in the accumulation area show that the present retreat is climate-induced and presumably not the quiescent phase of a surge cycle. The lower air temperatures at the end of the 19th century may have caused a larger fraction of the bed to be frozen, although the glacier terminus was steeper and thicker than at present. Another scenario is that pressure-melting temperatures dominated a larger part of the bed and that the boundary between cold and temperate ice was closer to the terminus than at present. On the photograph from 1923 (De Geer, 1930), large icings are present in front of the glacier, indicating a polythermal glacier regime (Hagen and others, 1993).

The good correlation between $b_{\mathrm{n}}$ and summer temperatures indicates that the 20th-century glacier retreat is in accordance with considerably lower summer temperatures in the previous century. The links between surge events and climate change are still unresolved, but it is tentatively suggested that midre Lovénbreen was a surge-type glacier whose last surge was climatically hastened by the LIA climate conditions. This is possible since midre Lovénbreen is a small glacier, liable to react relatively fast to climate changes. Thus, the domed fronts observed on several small valley glaciers in the area 100 years ago may actually have been surges, which coincided as a result of the LIA climate conditions.

The geomorphology in the area between the 1892 margin and the present glacier margin is apparently inconsistent with a non-surge-type classification. The occurrence of small concertina-like eskers in the area instead suggests a previous phase of surge behaviour as described by Knudsen (1995). Evans and Rea (1999) point out that no single landform or diagnostic criterion should be used as conclusive evidence of surge behaviour, but the landform assemblage of concertina eskers, thrust moraines, subglacial crevasse-squeeze ridges and hummocky moraine is a very strong indicator. All these landforms, except concertina eskers, are also characteristic of non-surge-type polythermal glaciers.

Nearby valley glaciers show evidence of having surged: a looped medial moraine is found on Pedersenbreen (Bennett and others, 1996), and a deformed esker exists near the terminal moraine in the foreland of vestre Lovénbreen (personal communication from O. Humlum, 2001). Pedersenbreen is not registered as surge-type in Hagen and others (1993), but Hambrey and others (1999) interpret the looped moraine as clear evidence of surge behaviour on Pedersenbreen. Vestre Lovénbreen has never been classified as a surge-type glacier. This suggests that certain features characteristic of surge behaviour may be so small that they are not easily recognized on aerial photographs. 


\section{CONGLUSIONS}

Midre Lovénbreen is probably an example of climateinduced change from surge-type to non-surge-type glacier behaviour. It has a history of being a polythermal glacier with surge behaviour, followed by a long period with a net balance so negative that the glacier is not building up in the accumulation area. Most of the glacier has frozen to the bed, and the glacier has changed from surge-type to nonsurge-type, during the 20th century.

The presence of small deformed eskers, concertina eskers, in the forefield of midre Lovénbreen appears to be geomorphological evidence of significant longitudinal compression near the glacier snout in the past, interpreted as surge behaviour. The eskers were probably englacially deformed during a surge and became subaerially exposed during the most recent phase of deglaciation.

\section{AGKNOWLEDGEMENTS}

Thanks to The University Courses on Svalbard (UNIS), who partly funded the fieldwork; and to S. Hanson who assisted in the field. The National Survey and Cadastre in Denmark kindly let me use their digital photogrammetry equipment to construct the orthophoto and the terrain model. H. Jiskoot and G. S. Hamilton reviewed the manuscript and helped to improve it substantially.

\section{REFERENGES}

Benn, D. I. and D. J. A. Evans. 1998. Glaciers and glaciation. London, Arnold. Bennett, M. R., D. Huddart, M.J. Hambrey and J. F. Ghienne. 1996. Moraine development at the high-Arctic valley glacier Pedersenbreen, Svalbard. Geogr. Ann., 78A(4), 209-222.

Björnsson, H. and 6 others. 1996. The thermal regime of sub-polar glaciers mapped by multi-frequency radio-echo sounding. F. Glaciol., 42(140), 23-32.

Brennand, T. A. 1994. Macroforms, large bedforms and rhythmic sedimentary sequences in subglacial eskers, south-central Ontario: implications for esker genesis and meltwater regime. Sediment. Geol., 91(1-4), 9-55.

De Geer, G. 1930. Flygfärder och polarforskning från Andrée till nutiden. Forden runt, 2, 577-609.

Dowdeswell, J. A., G. S. Hamilton and J. O. Hagen. 1991. The duration of the active phase on surge-type glaciers: contrasts between Svalbard and other regions. F. Glaciol., 37(127), 388-400.

Dowdeswell, J. A., R. Hodgkins, A.-M. Nuttall, J. O. Hagen and G. S. Hamilton. 1995. Mass balance change as a control on the frequency and occurrence of glacier surges in Svalbard, Norwegian High Arctic. Geophys. Res. Lett., 22(21), 2909-2912.

Dowdeswell, J. A. and 10 others. 1997. The mass balance of circum-Arctic glaciers and recent climate change. Quat. Res., 47(1), 1-14.

Evans, D. J. A. and B. R. Rea. 1999. Geomorphology and sedimentology of surging glaciers: a land-systems approach. Ann. Glaciol., 28, 75-82.

Evans, D. J. A., D. S. Lemmen and B. R. Rea. 1999. Glacial landsystems of the southwest Laurentide ice sheet: modern Icelandic analogues. 7 . Quat. Sci., 14(7), 673-691.

Fleming, K. M., J. A. Dowdeswell and J. Oerlemans. 1997. Modelling the mass balance of northwest Spitsbergen glaciers and responses to climate change. Ann. Glaciol., 24, 203-210.

Førland, E. J., I. Hanssen-Bauer and P. Ø. Nordli. 1997. Climate statistics and longterm series of temperatures and precipitation at Svalbard and Fan Mayen. Oslo, Det Norske Meteorologiske Institutt. (DNMI Klima Report 21/97.)

Hagen, J. O. and O. Liestøl. 1990. Long-term glacier mass-balance investigations in Svalbard, 1950-88. Ann. Glaciol., 14, 102-106.

Hagen, J. O. and A. Sætrang. 1991. Radio-echo soundings of sub-polar glaciers with low-frequency radar. Polar Res., 9(1), 99-107.

Hagen, J. O., O. Liestøl, E. Roland and T. Jørgensen. 1993. Glacier atlas of Svalbard and Jan Mayen. Nor. Polarinst. Medd. 129.

Hamberg, A. 1894. En resa til norra ishafet sommaren 1892. Ymer, 14, 25-61.

Hambrey, M. J. and J. A. Dowdeswell. 1997. Structural evolution of a surgetype polythermal glacier: Hessbreen, Svalbard. Ann. Glaciol., 24, 375-381.

Hambrey, M. J., J. A. Dowdeswell, T. Murray and P. R. Porter. 1996. Thrusting and debris entrainment in a surging glacier: Bakaninbreen, Svalbard. Ann. Glaciol., 22, 241-248.

Hambrey, M. J., D. Huddart, M. R. Bennett and N. F. Glasser. 1997. Genesis of "hummocky moraines" by thrusting in glacier ice: evidence from Svalbard and Britain. 7. Geol. Soc. London, 153(4), 623-632.

Hambrey, M. J., M. R. Bennett, J. A. Dowdeswell, N. F. Glasser and D. Huddart. 1999. Debris entrainment and transfer in polythermal valley glaciers. F. Glaciol., 45(149), 69-86.

Hamilton, G. S. and J. A. Dowdeswell. 1996. Controls on glacier surging in Svalbard. 7. Glaciol., 42(140), 157-168.

Hansen, S. 1999. A photogrammetrical, climate-statistical and geomorphological approach to the post Little Ice Age changes of the midre Lovénbreen glacier, Svalbard. (M.Sc. thesis, University of Copenhagen.)

Hart, J. K. 1999. Identifying fast ice flow from landform assemblages in the geological record: a discussion. Ann. Glaciol., 28, 59-66.

Isachsen, G. 1912. Résultats des campagnes scientifiques accomplies sur son yacht par Albert ler, Prince Souverain de Monaco. In Exploration dunordouest du Spitsberg entreprise sous les auspices de S.A.S. le Prince de Monaco par la mission Isachsen. Vol. 1. Monaco, Christiania. (Rapport 40.)

Jiskoot, H., T. Murray and P. Boyle. 2000. Controls on the distribution of surge-type glaciers in Svalbard. F. Glaciol., 46(154), 412-422.

Knudsen, Ó. 1995. Concertina eskers, Brúarjökull, Iceland: an indicator of surge-type behaviour. Quat. Sci. Rev., 14(5), 487-493.

Lefauconnier, B. and J. O. Hagen. 1991. Surging and calving glaciers in eastern Svalbard. Nor. Polarinst. Medd. 116.

Liestøl, O. 1988. The glaciers in the Kongsfjorden area, Spitsbergen. Nor. Geogr. Tidsskr., 42 (4), 231-238.

Liestøl, O. 1993. Glaciers of Europe - glaciers of Svalbard, Norway. U.S. Geol. Surv. Prof. Pap. 1386-E, E127-E151.

Meier, M. F. and A. Post. 1969. What are glacier surges? Can. 7. Earth Sci., 6(4), Part 2, 807-817.

Murray, T. and 6 others. 2000. Glacier surge propagation by thermal evolution at the bed. 7. Geophys. Res., 105(B6), 13,491-13,507.

Nordli, P. Ø., I. Hanssen-Bauer and E. J. Førland. 1996. Homogeneity analyses of temperature and precipitation series from Svalbard and Jan Mayen. Oslo, Det Norske Meteorologiske Institutt. (DNMI Klima Report 16.)

Raymond, C., T. Jóhannesson, T. Pfeffer and M. Sharp. 1987. Propagation of a glacier surge into stagnant ice. f. Geophys. Res., 92(B9), 9037-9049

Sharp, M. 1985. Sedimentation and stratigraphy at Eyjabakkajökull - an Icelandic surging glacier. Quat. Res., 24(3), 268-284.

Sharp, M. 1988. Surging glaciers: geomorphic effects. Prog. Phys. Geogr., 12(4), $533-559$. 